\title{
KENNETH W. STEWART, 1935-2012: OBITUARY AND LIST OF PUBLICATIONS
}

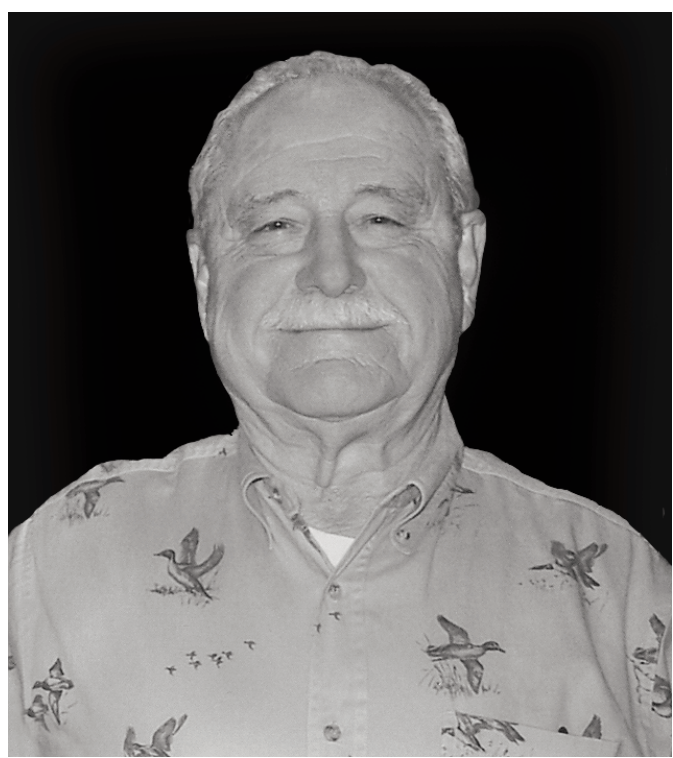

Kenneth W. Stewart

Kenneth Wilson Stewart was born to Bill and Dorothy McAlister Wilson on 5 March 1935 in Walters, Cotton County, Oklahoma, and grew up in the home of his stepfather, Anderson Stewart, and mother, Dorothy McAlister Stewart. He graduated from Hugoton (Kansas) High School in 1953 and married Francene Brewer of Hugoton in 1956. Together they raised 3 children, Dana, Daryl, and Dwight. Ken attended Oklahoma State University (then Oklahoma A\&M) and received his B.S. in Forestry/Botany in 1958, his M.S. in Entomology in 1959, and a Ph.D. in Entomology/Zoology in 1963. He worked during the summer months for the U.S. Soil Conservation Service and the U.S. Forest Service in 1954, 1956, and 1958 and took his first academic position as a biology instructor at Coffeyville (Kansas) College for the 1960/61 school year before moving to the University of North Texas (UNT) in Denton, Texas, where he served as a full-time faculty member in the
Department of Biological Sciences from 1961 to 2000 , as Chairman of the department from 1979 to 1983, and as Director of the Division of Environmental Sciences from 1988 to 1990. In 1994, he was appointed Regents Professor by the Texas Board of Regents and he continued as Regents Professor Emeritus and Adjunct Research Professor in the UNT Biology department until his death on 9 December 2012. In addition to these appointments, Ken served as Visiting Professor at the University of Oklahoma Biological Station during the summers of 1966, 1991, and 1993 and at the University of Montana Biological Station during the summer months of 1981, 1985, 1987, and 1989.

At UNT, Ken taught several graduate and undergraduate courses including Freshman Zoology, Environmental Biology, Conservation Management, Entomology, and Aquatic Entomology. He was a master teacher noted for delivery of organized lectures filled with the intricate and fascinating details peculiar to the systematics, biogeography, trophic dynamics, drift, and behavior of stoneflies and other creatures. During his career he supervised 43 graduate students who completed 25 M.S. and $21 \mathrm{Ph} . \mathrm{D}$. degrees. His personal research evolved over the years, and perhaps an epiphany-like experience occurred in 1968 with the discovery of a population of the stonefly Perlesta placida in nearby Denton Creek; this discovery prompted his first stonefly study on reproductive morphology and mating behavior in Perlesta, coauthored with Gerald Atmar and Bernie Solon in 1969. Although stoneflies became the focus of his subsequent research, he continued to work with students on a variety of other groups including odonates, spiders, mayflies, caddisflies, hellgrammites, lepidopterans, nematodes, and fish. His publication record includes 191 articles, book chapters, and books authored singly or with 67 different coauthors. Frequent topics of study include life histories, food habits, faunistics, drift, and benthic ecology, but many of Ken's studies are based on the analysis of drumming signals among stoneflies. 
Early work on this topic was done by European workers such as Rainier Rupprecht, but Ken, together with a cadre of students and colleagues (Stan Szczytko, David Zeigler, Rosalyn Snellen, Monchan Maketon, Rodney Hassage, Boris Kondratieff, Fred Kirchner, Richard Bottorff, Steve Moulton, Kevin Alexander, John Abbott, J.M. Tierno de Figueroa, J.M. LuzonOrtega, and John Sandberg), became the unquestioned leaders of this line of investigation as collectively they moved the process through several phases of technology, addressed many of the basic questions, and helped in development of standards for signal analysis.

In 1978, inspired by the publication of 2 classic works on larval aquatic insects (Edmunds, Jensen, and Berner's 1976 book on mayflies and Wiggins' 1977 book on caddis larvae), Ken initiated a similar study on stonefly larvae, together with Bill Stark, which led to publication of, perhaps, his most noteworthy work, Nymphs of North American Stonefly Genera (Plecoptera) published in 1988, reprinted in 1993, and released in a second edition in 2002. A major part of this study involved collecting specimens of several rare genera unknown in the larval stage, and this led Ken and his colleagues on numerous forays in search of these stoneflies. Although all these trips were iconic in their own way, one which stands out for the authors became known (to us) as the "Great Stonefly Expedition of 1979." A major target for this trip was the nemourid genus Lednia, known at the time from a few adults collected in 2 glacial streams in Montana's Glacier National Park. There, in a small stream at Logan Pass on 20 and 22 July 1979, the 3 of us (Stewart, Baumann, and Stark) collected 42 mature, preemergent Lednia nymphs, the first documentation of the immature stage of this interesting genus. A photograph made of Ken on 20 July in Logan Creek was published by Stark, Szczytko, and Nelson on page 8 in their 1998 book American Stoneflies: A Photographic Guide to the Plecoptera. Ken's exuberence and passion for the scientific study of drumming and nymphal associations of stoneflies were celebrated in "Yep, Another Nymphmaniac" an article written by Robert Boyle and published in Sports Illustrated in 1980. Ken is also mentioned prominently in Leiser and Boyle's book Stoneflies for the Angler published in 1982. The nymph project became a major part of his life's work and he often reminded himself and colleagues that "the logical continuation" of the nymph work was the association and study of additional species in order to test the validity of descriptions and keys. Several of us are still actively involved in exercising this "logical continuation" as we attempt to complete studies initiated with Ken in recent months. Colleagues who have collaborated recently with Ken in these studies include Norm Anderson, Richard Baumann, Eugene Drake, Jane Earle, Fred Kirchner, Boris Kondratieff, John Sandberg, Larry Serpa, Bill Stark, and Stan Szczytko. Ken also collected in Alaska for many years and collaborated with Mark Oswood in a study of stoneflies of Alaska and western Canada published by The Caddis Press in 2006, and he coauthored the stonefly chapter with Peter Harper in Merritt and Cummins' 2nd and 3rd editions of $A n$ Introduction to the Aquatic Insects of North America and with Bill Stark in the 4th edition (Merritt, Cummins, and Berg).

Although not the major thrust of his work, Ken coauthored several taxonomic papers with students and colleagues (Kevin Alexander, Richard Bottorff, Ed DeWalt, Mark Ernst, Jack Feminella, Fred Kirchner, Boris Kondratieff, Steve Moulton, Mark Oswood, Barry Poulton, Jean Stanger, Bill Stark, and Stan Szczytko) in which species (or genera) of stoneflies or caddisflies were proposed. The list includes 28 stonefly species, 6 caddisfly species, and 6 stonefly genera (Alaskaperla Stewart \& DeWalt, 1991; Baumannella Stark \& Stewart, 1985; Cascadoperla Szczytko \& Stewart, 1979; Oconoperla Stark \& Stewart, 1982; Susulus Bottorff \& Stewart, 1989; Tallaperla Stark \& Stewart, 1981). In addition, Ken has been honored with 3 patronyms: Beloneuria stewarti Stark \& Szczytko, 1976; Neoperla stewarti Stark \& Baumann, 1978, and Zealeuctra stewarti Kondratieff \& Zuellig, 2004.

Ken was a leader in several scientific societies including the North American Benthological Society (now Society for Freshwater Science) and the International Society for Plecopterologists. He served the former group as president in 1978-1979 and was later honored by that group in 1997 with the Award of Excellence in Benthic Science. He served the latter group for many years as a member of the organizing committee and as managing editor of Perla, the organization's newsletter, and was 
honored in 2001 with the Lifetime Achievement Award in recognition of his outstanding contributions to plecopterology. Ken was an active member of the American Entomological Society for more than 30 years and the Entomological Society of America for more than 40 years. In 1973, he and Richard Baumann were instrumental in organizing a formal Aquatic Insects Subsection of the ESA. More recently, Ken was honored by the sports magazine Outdoor Life as a 2010 member of the "Outdoor Life 25," a group of 25 individuals selected as leaders whose work has been of great significance in conservation. Ken also served on the Advisory Board for Illiesia, Journal of Stonefly Research, until his death and was a true ambassador for stoneflies and healthy streams throughout his career. Perhaps in an effort to increase appreciation for stoneflies among the general public, he invited representatives of the local Dallas media into his lab for a "stonefly fry," an event surely immortalized at least among his students and members of the stonefly community.

The publications listed below include those authored or coauthored by Ken and extracted by us from his resume. We thank his wife, Francene, for providing the resume and we also thank Stan Szczytko, Boris Kondratieff, Ed DeWalt, and Steve Moulton for their assistance in preparation of this manuscript.

Bill P. Stark
Department of Biology
Mississippi College
Clinton, MS 39058
E-mail: stark@mc.edu
RichardW. Baumann
Department of Biology o Monte L. Bean
Life Science Museum
Brigham Young University
Provo,UT84602
E-mail: richard_baumann@byu.edu

\section{List of Publications}

1964. Stewart, K.W., and R.R. Walton. Oviposition and establishment of the Southwestern corn borer on corn. Journal of Economic Entomology 57(5): $628-631$

1965. Stewart, K.W., and R.R. Walton. Extension of the incubation period of Southwestern corn borer eggs by refrigeration. Journal of Economic Entomology 58(3):579-580.

1965. STEWART, K.W. Observations on the life history and habits of Scierus annectens Lec. (Coleoptera:
Scolytidae). Annals of the Entomological Society of America 58(6):924-927.

1966. Stewart, K.W., and H.E. SChlichting JR. Dispersal of algae and protozoa by selected aquatic insects. Journal of Ecology 54:551-562.

1966. Parsons, M.W., H.E. Schlichting Jr., and K.W. STEWART. In-flight transport of algae and protozoa by selected Odonata. Transactions of the American Microscopy Society 85(4):520-527.

1967. Revill, D.L., AND K.W. STEWART. Dispersal of viable algae and protozoa by horseflies and mosquitoes (Diptera: Tabanidae, Culicidae). Annals of the Entomological Society of America 60(5):1077-1081.

1967. Horner, N.W., and K.W. Stewart. Life history of the brown spider, Loxosceles reclusa Gertsch and Mulaik. Texas Journal of Science 19(4):333-347.

1967. Revill, D.L., K.W. Stewart, and H.E. SchlichtING JR. Passive dispersal of viable algae and protozoa by selected craneflies and midges. Ecology 48(6):1023-1027.

1968. SteWART, K.W., AND R. MurPhy JR. Notes on interpond dispersion of some marked adult dragonflies in Oklahoma. Texas Journal of Science 20(2): $177-182$.

1969. Stewart, K.W., G.L. Atmar, and B.M. Solon. Reproductive morphology and mating behavior of Perlesta placida (Plecoptera: Perlidae). Annals of the Entomological Society of America 62(6):1433-1438.

1970. Stewart, K.W., L.E. Milliger, and B.M. Solon. The dispersal of algae, protozoa and fungi by aquatic Hemiptera, Trichoptera and other aquatic insects. Annals of the Entomological Society of America 63(1):139-144.

1971. Milliger, L.M., K.W. Stewart, and J.K.G. Silvey. The passive dispersal of viable algae, protozoans and fungi by aquatic and terrestrial Coleoptera. Annals of the Entomological Society of America 64(1):36-45.

1971. Stewart, K.W. Aquatic insects of Texas; Mayflies. Texas Parks and Wildlife 29(2):26-29.

1971. Stewart, K.W. Aquatic insects of Texas; Dragonflies and damselflies. Texas Parks and Wildlife 29(3): 24-27.

1971. SteWART, K.W. Aquatic insects of Texas; Stoneflies. Texas Parks and Wildlife 29(4):6-9.

1971. Stewart, K.W. Aquatic insects of Texas; Caddisflies. Texas Parks and Wildlife 29(5):24-27.

1971. Stewart, K.W. Aquatic insects of Texas; Aquatic bugs. Texas Parks and Wildlife 29(6):23-25.

1971. Stewart, K.W. Aquatic insects of Texas; Dobsonflies and alderflies. Texas Parks and Wildlife 29(7): $12-15$.

1971. Stewart, K.W. Aquatic insects of Texas; Aquatic beetles. Texas Parks and Wildlife 29(8):24-27.

1971. Stewart, K.W. Aquatic insects of Texas; Aquatic flies. Texas Parks and Wildlife 29(9):24-27.

1972. ATMAR, G.L., AND K.W. STEWART. Food, feeding and ecological efficiencies of Fundulus notatus (Raf.) (Osteichthyes; Cyprinodontidae). American Midland Naturalist 88(1):76-89.

1972. Solon, B.M., And K.W. Stewart. Dispersal of algae and protozoa via the alimentary tracts of 
selected aquatic insects. Environmental Entomology 1(3):309-314.

1972. StewarT, K.W. Fiddleback; the brown recluse spider in Texas. Texas Parks and Wildlife 30(4):20-23.

1972. Stewart, K.W. Pest species, food web index, species diversity, air pollution and aquatic and terrestrial invertebrates. In: A systems evaluation of the environmental impact of the Aubrey Reservoir project on Elm Fork of the Trinity River in North Texas. North Texas State University Institution of Environmenal Studies Final Report to U.S. Army Corps Engineers, Contract \#DACW63-72-0052.

1973. Maki, A.W., K.W. Stewart, and J.K.G. Silvey. The effects of Dibrom on respiratory activity of the stonefly Hydroperla crosbyi, hellgrammite Corydalus cornutus and the golden shiner Notemigonus crysoleucas. Transactions of the American Fisheries Society 102(4):806-815.

1973. Stark, B.P., and K.W. StEWart. New species and descriptions of stoneflies (Plecoptera) from Oklahoma. Entomological News 84:192-197.

1973. Stewart, K.W., G.P. Friday, and R.E. Rhame. Food habits of the hellgrammite Corydalus cornutus L. (Megaloptera: Corydalidae) in the Brazos River, Texas. Annals of the Entomological Society of America 66(5):959-963.

1973. Gardenhire, H.J., N.F. Tuleen, and K.W. SteWart. Trisomic analysis of greenbug resistance in barley, Hordeum vulgare L. Crop Science 13:684-685.

1973. Stark, B.P., and K.W. Stewart. Distribution of stoneflies (Plecoptera) of Oklahoma. Journal of the Kansas Entomological Society 46(4):563-577.

1974. Stewart, K.W., R.W. Baumann, and B.P. Stark. The distribution and past dispersal of southwestern United States Plecoptera. Transactions of the American Entomological Society 99:507-546.

1974. Vaught, G.L., and K.W. Stewart. The life history and ecology of the stonefly Neoperla clymene (Newman) (Plecoptera: Perlidae). Annals of the Entomological Society of America 67(2):167-178.

1974. SteWart, K.W., AND S.W. SzczYTKo. A new species of Taeniopteryx from Texas (Plecoptera: Taeniopterygidae). Journal of the Kansas Entomological Society 47(4):451-458.

1974. Cloud, T.J., Jr., and K.W. Stewart. The drift of mayflies (Ephemeroptera) in the Brazos River, Texas. Journal of the Kansas Entomological Society 47(3): 379-396.

1974. Cloud, T.J., Jr., ANd K.W. Stewart. Seasonal fluctuations and periodicity in the drift of caddisfly larvae (Trichoptera) in the Brazos River, Texas. Annals of the Entomological Society of America 67(5):805-811.

1975. SteWART, K.W. An improved elutriator for separating stream insects from stony substrates. Transactions of the American Fisheries Society 104:821-823.

1976. McClure, R.G., And K.W. Stewart. Life cycle and production of the mayfly Choroterpes (Neochoroterpes) mexicanus Allen (Ephemeroptera: Leptophlebiidae). Annals of the Entomological Society of America 69:134-144.

1976. Poole, W.C., and K.W. Stewart. The vertical distribution of macrobenthos within the substratum of the Brazos River, Texas. Hydrobiologia 50:151-160.
1976. Rhame, R.E., and K.W. Stewart. Life cycles and food habits of three Hydropsychidae (Trichop tera) species in the Brazos River, Texas. Transactions of the American Entomological Society 102: 65-99.

1976. Stewart, K.W., and B.P. Stark. Reproductive system and mating of Hydroperla crosbyi (Needham and Claassen); a newly discovered method of sperm transfer in Insecta. Oikos 28:84-89.

1976. Stewart, K.W., B.P. Stark, and T.G. Huggins. The stoneflies (Plecoptera) of Louisiana. Great Basin Naturalist 36(3):366-384.

1976. SzczytKo, S.W., And K.W. Stewart. Nymphs and adults of three new species of Nearctic Isoperla (Plecoptera). Great Basin Naturalist 36(2):211-220.

1977. SzczytKo, S.W., and K.W. Stewart. The stoneflies (Plecoptera) of Texas. Transactions of the American Entomological Society 103:327-378.

1977. Zeigler, D.D., and K.W. Stewart. Drumming behavior of eleven Nearctic stonefly (Plecoptera) species. Annals of the Entomological Society of America 70:495-505.

1977. Oberndorfer, R.Y., and K.W. Stewart. The life cycle of Hydroperla crosbyi (Needham and Claassen) (Plecoptera: Perlodidae). Great Basin Naturalist 37: 260-273.

1977. Fuller, R.L., and K.W. Stewart. The food habits of stoneflies (Plecoptera) in the upper Gunnison River, Colorado. Environmental Entomology 6: 302-392.

1977. Stewart, K.W., and D.G. Huggins. Kansas Plecoptera (Stoneflies). Technical Publication of the State Biological Survey of Kansas 4:31-40.

1977. Stewart, K.W. Formation of the Aquatic Insects Subsection, ESA. Bulletin of the Entomological Society of America 23(4):245-246.

1978. SzczYTKo, S.W., AND K.W. SteWART. Isoperla bilineata: designation of a neotype and allotype, and further descriptions of egg and nymph. Annals of the Entomological Society of America 71:212-217.

1979. Fuller, R.L., and K.W. Stewart. Stonefly (Plecoptera) food habits and prey preference in the Dolores River, Colorado. American Midland Naturalist 101:170-181.

1979. SzCZYTKO, S.W., AND K.W. SteWart. Stonefly drumming as a model classroom study of aquatic insect behavior. Pages 31-37 in V.H. Resh and D.M. Rosenberg, editors, Innovative teaching in aquatic entomology. Canadian Special Publication of Fisheries and Aquatic Sciences, Volume 43.

1979. StEWART, K.W. A module for advanced field exercises in aquatic entomology. Pages 95-100 in V.H. Resh and D.M. Rosenberg, editors, Innovative teaching in aquatic entomology. Canadian Special Publication of Fisheries and Aquatic Sciences, Volume 43.

1979. Szczytko, S.W., And K.W. Stewart. The genus Isoperla (Plecoptera) of western North America; Holomorphology and systematics, and a new stonefly genus Cascadoperla. Memoirs of the American Entomological Society 32:1-120.

1979. Snellen, R.K., And K.W. Stewart. The life cycle of Perlesta placida (Hagen) (Plecoptera: Perlidae) 
in a Texas intermittent stream. Annals of the Entomological Society of America 72:659-666.

1979. Snellen, R.K., and K.W. Stewart. The life cycle and drumming behavior of Zealeuctra claasseni (Frison) and Zealeuctra hitei Ricker and Ross (Plecoptera: Leuctridae) in Texas, U.S.A. Aquatic Insects 1:65-89.

1979. SzczytKo, S.W., and K.W. Stewart. Drumming behavior of four western Nearctic Isoperla (Plecoptera) species. Annals of the Entomological Society of America 72:781-786.

1980. Fullington, K.E., And K.W. Stewart. Nymphs of the stonefly genus Taeniopteryx (Plecoptera: Taeniopterygidae) of North America. Journal of the Kansas Entomological Society 53:237-259.

1980. Baumann, R.W., and K.W. Stewart. The nymph of Lednia tumana (Ricker) (Plecoptera: Nemouridae). Proceedings of the Entomological Society of Washington 72:655-659.

1980. Grant, P.M., and K.W. SteWart. The life history of Isonychia sicca (Ephemeroptera: Siphlonuridae) in an intermittent stream in north central Texas. Annals of the Entomological Society of America 73: $747-755$.

1981. Stark, B.P., and K.W. Stewart. The Nearctic genera of Peltoperlidae (Plecoptera). Journal of the Kansas Entomological Society 54:285-311.

1981. Stark, B.P., AND K.W. SteWART. Lectra szczytkoi, a new stonefly from Louisiana (Plecoptera: Leuctridae). Entomological News 92:91-92.

1981. SzczytKo, S.W., and K.W. Stewart. Reevaluation of the genus Clioperla. Annals of the Entomological Society of America 74:563-569.

1982. Stark, B.P., and K.W. Stewart. Notes on Perlinodes aurea (Smith) (Plecoptera: Perlodidae). Annals of the Entomological Society of America 75:84-88.

1982. Stark, B.P., AND K.W. SteWART. The nymph of Viehoperla ada (Plecoptera: Peltoperlidae). Journal of the Kansas Entomological Society 55:494-498.

1982. Stewart, K.W., S.W. SZcZYTKo, and B.P. Stark. Drumming behavior of four species of North American Pteronarcyidae (Plecoptera): dialects in Colorado and Alaska Pteronarcella badia. Annals of the Entomological Society of America 75: $530-533$.

1982. Stewart, K.W., S.W. Szczytko, B.P. Stark, and D.D. Zeigler. Drumming behavior of six North American Perlidae (Plecoptera) species. Annals of the Entomological Society of America 75:549-554.

1982. StaRK, B.P., AND K.W. SteWART. Oconoperla, a new genus of North American Perlodinae (Plecoptera: Perlodidae). Proceedings of the Entomological Society of Washington 84:746-752.

1983. Shepard, W.D., and K.W. STEWART. A comparative study of nymphal gills in North American stonefly (Plecoptera) genera and a new, proposed paradigm of Plecoptera gill evolution. Miscellaneous Publications of the Entomological Society of America 55: $1-58$.

1983. Stark, B.P., K.W. Stewart, and J. Feminella. New records and descriptions of Alloperla (Plecoptera: Chloroperlidae) from the Ozark-Ouachita region. Entomological News 94:55-59.
1983. SteWart, K.W., S.W. SzcZYTKO, and B.P. Stark. The language of stoneflies. BioScience 33:117-118.

1983. Stewart, K.W., and S.W. SzczYTKo. The drift of Ephemeroptera and Plecoptera in two Colorado rivers. Freshwater Invertebrate Biology 2: 117-131.

1984. Harper, P.P., and K.W. Stewart. Plecoptera. Pages 182-229 in R. Merritt. and K. Cummins, editors, An introduction to the aquatic insects of North America. 2nd edition, Chapter 14. Kendall/Hunt Publishing Co., Dubuque, Iowa. 722 pp.

1984. Stewart, K.W., AND D.D. Zeigler. The use of larval morphology and drumming in Plecoptera systematics, and further studies of drumming behavior. Annales de Limnologie 20:105-114.

1984. Stewart, K.W., and D.D. Zeigler. Drumming behavior of 12 North American stonefly (Plecoptera) species: first descriptions in Peltoperlidae, Taeniopterygidae and Chloroperlidae. Aquatic Insects 6:49-61.

1984. Szczytko, S.W., And K.W. Stewart. Descriptions of Calliperla Banks, Rickera Jewett, and two new western Nearctic Isoperla species (Plecoptera: Perlodidae). Annals of the Entomological Society of America 77:251-263.

1984. Stewart, K.W., AND B.P. Stark. Nymphs of North American Perlodinae genera. Great Basin Naturalist 44:373-415.

1984. Ernst, M.R., T.L. Beitinger, and K.W. Stewart. Critical thermal maxima of nymphs of three Plecoptera species from an Ozark foothills stream. Journal of Freshwater Invertebrate Biology 3:80-85.

1984. Maketon, M., and K.W. SteWart. The drumming behavior of four North American Perlodidae (Plecoptera) species. Annals of the Entomological Society of America 77:621-626.

1984. Maketon, M., AND K.W. Stewart. Further studies of drumming behavior of North American Perlidae (Plecoptera). Annals of the Entomological Society of America 77:770-778.

1985. Stewart, K.W., and J.A. Stanger. The nymphs, and a new species of North American Setvena Illies (Plecoptera: Perlodidae). Pan-Pacific Entomologist 61:237-244

1985. Feminella, J.W., and K.W. Stewart. Diet and predation in three leaf-associated stoneflies (Plecoptera) in an Arkansas mountain stream. Freshwater Biology 16:521-538.

1985. Stewart, K.W., and J.A. Stanger. The nymph of Bisancora rutriformis Surdick (Plecoptera: Chloroperlidae). Proceedings of the Entomological Society of Washington 87:526-529.

1985. Ernst, M.R., and K.W. SteWart. Emergence patterns and an assessment of collecting methodologies for adult stoneflies (Plecoptera) in an Ozark foothill stream. Canadian Journal of Zoology 63: 2962-2968.

1985. Todd, C.S., AND K.W. Stewart. Food habits and dietary overlap of non-game insectivorous fishes in Flint Creek, Oklahoma, a western Ozark foothills stream. Great Basin Naturalist 45:721-733.

1985. Zeigler, D.D., and K.W. Stewart. Drumming behavior of five stonefly (Plecoptera) species from 
central and western North America. Annals of the Entomological Society of America 78:717-722

1985. Stark, B.P., AND K.W. SteWARt. Baumannella, a new perlodine genus from California (Plecoptera: Perlodidae). Proceedings of the Entomological Society of Washington 87:740-745.

1985. Ernst, M.R., and K.W. SteWart. Growth and drift of nine stonefly species (Plecoptera) in an Oklahoma Ozark foothills stream and conformation to regression models. Annals of the Entomological Society of America 78:635-646.

1985. Zeigler, D.D., AND K.W. Stewart. Age effects on the drumming behavior of Pteronarcella badia (Plecoptera) males. Entomological News 96:157-160.

1986. Zeigler, D.D., And K.W. Stewart. Female response thresholds of two stonefly (Plecoptera) species to computer-simulated and modified male drumming calls. Animal Behavior 34:929-931.

1986. Ernst, M.R., B.C. Poulton, and K.W. Stewart. Neoperla (Plecoptera: Perlidae) of the southern Ozark and Ouachita mountain region, and two new species of Neoperla. Annals of the Entomological Society of America 79:645-661.

1986. Ernst, M.R., And K.W. Stewart. Microdistribution of stoneflies (Plecoptera) in relation to organic matter in an Ozark foothills stream. Aquatic Insects $8: 237-254$.

1987. Jop, K.M., AND K.W. Stewart. Annual stonefly (Plecoptera) production in a second order Oklahoma Ozark stream. Journal of the North American Benthological Society 6:26-34

1987. Poulton, B.C., And K.W. Stewart. Three new species of stoneflies (Plecoptera) from the OzarkOuachita mountain region. Proceedings of the Entomological Society of Washington 89:296-302

1987. Zeigler, D.D., and K.W. Stewart. Behavioral characters with systematic potential in stoneflies (Plecoptera). Proceedings of the Entomological Society of Washington 89:794-802.

1988. KondratiefF, B.C., R.F. KirChner, And K.W. Stewart. A review of Perlinella Banks (Plecoptera: Perlidae). Annals of the Entomological Society of America 81:19-27.

1988. SteWART, K.W., AND B.P. STARK. Nymphs of North American stonefly genera (Plecoptera). Volume 12. Thomas Say Foundation. Entomological Society of America. 460 pp.

1988. Hassage, R.L., K.W. Stewart, and D.D. Zeigler. Female response to computer-simulated male drumming call variations in Pteronarcella badia (Plecoptera: Pteronarcyidae). Annals of the Entomological Society of America 81:528-531.

1988. Maketon, M., and K.W. Stewart. Patterns and evolution of drumming behavior in the stonefly families Perlidae and Peltoperlidae. Aquatic Insects 10:77-98.

1988. Maketon, M., K.W. Stewart, B.C. Kondratieff, AND R.F. KiRCHNER. New descriptions of drumming, and evolution of the behavior, in North American Perlodidae (Plecoptera). Journal of the Kansas Entomological Society 61:161-168.

1988. Stewart, K.W., S.W. SzczytKo, and M. Maketon. Drumming as a line of evidence for delineating species in the Plecoptera genera Isoperla, Pteronarcys and Taeniopteryx. Annals of the Entomological Society of America 81:689-699.

1988. Poulton, B.C., and K.W. Stewart. Aspects of flight behavior in Calineuria californica (Plecoptera: Perlidae) from a Rocky Mountain Lake outlet system. Entomological News 99:125-133.

1988. Hassage, R.L., R.E. DeWalt, and K.W. Stewart. Aggregation of Pteronarcella badia nymphs and effects of interaction with Claassenia sabulosa (Plecoptera). Oikos 53:37-40.

1989. Poulton, B.C., T.L. Beitinger, and K.W. Stewart. The effect of hexavalent chromium on the critical thermal maximum and body burden of Clioperla clio (Plecoptera: Perlodidae). Archives of Environmental Contamination and Toxicology 18: $594-600$.

1989. Bottorff, R.L., K.W. Stewart, and A.W. Knight. Description and drumming of Susulus, a new genus of stonefly (Plecoptera: Perlodidae) from California. Annals of the Entomological Society of America 82:545-554.

1990. Stewart, K.W., and M. MaKeton. Intraspecific variation and information content of drumming in three Plecoptera species. Pages 259-268 in I. Campbell, editor, Mayflies and stoneflies: life histories and biology. Proceedings of the 5th International Ephemeroptera Conference and the 9th International Plecoptera Conference. Volume 44, Series Entomologica. Kluwer Academic Publishers, Dordrecht/Boston/London.

1990. Stewart, K.W., R.L. Hassage, S.J. Holder, and M.W. Oswood. Life cycles of six stonefly species (Plecoptera) in subarctic and arctic Alaska streams. Annals of the Entomological Society of America 83:207-214

1990. Hassage, R.L., and K.W. Stewart. Growth and voltinism of five stonefly species in a New Mexico mountain stream. Southwestern Naturalist 35: 130-134

1990. Morris, J.R., K.W. Stewart, and R.L. Hassage. Use of the nematode Steinernema carpocapsae for control of the red imported fire ant (Hymenoptera: Formicidae). Florida Entomologist 73:675-677.

1991. Moring, J.B., R.L. Hassage, and K.W. Stewart. Behavioral interactions among male and female nymphs of the predatory stonefly Hydroperla crosbyi (Plecoptera: Perlodidae). Annals of the Entomological Society of America 84:207-211.

1991. Stewart, K.W., And M. MaKeton. Structures used by Nearctic stoneflies (Plecoptera) for drumming, and their relationship to behavioral pattern diversity. Aquatic Insects 13:33-53.

1991. Stewart, K.W., R.L. Bottorf, A.W. Knight, and J.B. MoRIng. Drumming of four North American Euholognathan stonefly species and a new complex signal pattern in Nemoura spiniloba Jewett (Plecoptera: Nemouridae). Annals of the Entomological Society of America 84:201-206.

1991. Poulton, B.C., and K.W. Stewart. The stoneflies of the Ozark and Ouachita Mountains (Plecoptera). Memoirs of the American Entomological Society 38:1-116. 
1991. Hassage, R.L., and K.W. Stewart. Use of substrate volume and void space to examine the presence of three stonefly species (Plecoptera) among stream habitats. Annals of the Entomological Society of America 84:309-315.

1991. Stewart, K.W., R.E. DeWalt, and M.W. Oswood. Alaskaperla, a new stonefly genus (Plecoptera: Chloroperlidae), and further descriptions of related Chloroperlidae. Annals of the Entomological Society of America 84:239-247.

1992. Moring, J.B., AND K.W. Stewart. Influence of sex and egg-case presence on predatory behavior of the wolf spider Pardosa valens Barnes (Araneae: Lycosidae). Southwestern Naturalist 37:132-137.

1992. Moulton, S.R., II, and K.W. Stewart. A new species of Ceraclea (Trichoptera: Leptoceridae) from the Ozark Mountains of Missouri, USA. Proceedings of the Entomological Society of Washington 94:361-365.

1992. StEWART, K.W. Environmental requirements of Plecoptera of the lower coastal southeast United States. Pages 1-6 in W.T. Mason, editor, Benthic ecology database catalogue of the environmental requirements committee. Florida Association of Benthologists. Section 6.

1992. Аввотт, J.C., and K.W. Stewart. Male search behavior of the stonefly Pteronarcella badia (Hagen) (Plecoptera: Pteronarcyidae). Journal of Insect Behavior 6:467-481.

1993. Moulton, S.R., II, D. Petr, and K.W. Stewart. Caddisflies (Insecta: Trichoptera) of the Brazos River drainage in north central Texas. Southwestern Naturalist 38:19-23.

1993. Moulton, S.R., II, and K.W. Stewart. A new species of the Polycentropus cinereus group from Arkansas and Texas (Trichoptera: Polycentropodidae). Entomological News 104:35-38.

1993. Moulton, S.R., II, AND K.W. Stewart. The Nearctic Oecetis scala group (Trichoptera: Leptoceridae) with the description of two new species from the Interior Highlands. Annals of the Entomological Society of America 86:221-227.

1993. Moulton, S.R., II, T.L. Beitinger, K.W. Stewart, AND R.J. CURRIE. Upper temperature tolerance of four species of caddisflies (Insecta: Trichoptera). Journal of Freshwater Ecology 8:193-198.

1994. Stewart, K.W. Theoretical considerations of mate finding and other adult behaviors of Plecoptera. Aquatic Insects 16:95-104.

1994. Moulton, S.R., II, K.W. Stewart, and K.L. YounG. New records, distribution and taxonomic status of some northern Arizona and Texas caddisflies (Insecta: Trichoptera). Entomological News 105:164-174.

1994. Stewart, K.W. Animal and human biology class notes, Biology 1610. William C. Brown Publishers, Dubuque, Iowa. $151 \mathrm{pp}$.

1994. DeWalt, R.E., K.W. Stewart, S.R. Moulton II, AND J.H. Kennedy. Summer biodiversity and emergence of mayflies, stoneflies and caddisflies from a Colorado mountain stream. Southwestern Naturalist 39:249-256.

1994. Moring, J.B., and K.W. Stewart. Habitat partitioning by the wolf spider (Araneae, Lycosidae) guild in streamside and riparian vegetation zones of the Conejos River, Colorado. Journal of Arachnology 22:205-217.

1995. Stewart, K.W., J.C. Авbott, and R.L. Bottorff. The drumming signals of two stonefly species Cosumnoperla hypocrena (Perlodidae) and Paraperla wilsoni (Chloroperlidae); a newly discovered duet pattern in Plecoptera. Entomological News 106:13-18.

1995. Stewart, K.W., J.C. Авbott, R.F. Kirchner, and S.R. Moulton II. New descriptions of North American Euholognathan stonefly drumming (Plecoptera) and first Nemouridae ancestral call discovered in Soyedina carolinensis (Plecoptera: Nemouridae). Annals of the Entomological Society of America 88:234-239.

1995. DeWaLt, R.E., and K.W. StEWART. Life histories of stoneflies (Plecoptera) in the Rio Conejos, Colorado. Great Basin Naturalist 55:1-18.

1996. Stewart, K.W., and P.P. Harper. Plecoptera. Pages 217-266 in R.W. Merritt and K.W. Cummins, editors, An introduction to the aquatic insects of North America. 3rd edition, Chapter 14. Kendall/ Hunt Publishing Company, Dubuque, Iowa.

1996. Alexander, K.D., and K.W. Stewart. Description and theoretical considerations of mate finding and other adult behaviors in a Colorado population of Claassenia sabulosa (Plecoptera: Perlidae). Annals of the Entomological Society of America 89:290-296.

1996. Alexander, K.D., and K.W. Stewart. The mate searching behavior of Perlinella drymo (Newman) (Plecoptera: Perlidae) in relation to drumming on a branched system. Bulletin of the Swiss Entomological Society 69:121-126.

1996. Moulton, S.R., II, and K.W. Stewart. Caddisflies (Trichoptera) of the Interior Highlands of North America. Memoirs of the American Entomological Institute. Volume 56. Gainesville, Florida. 425 pp.

1997. Moulton, S.R., II, and K.W. Stewart. A preliminary checklist of Texas caddisflies (Trichoptera). Pages 349-353 in Proceedings of the VIII International Symposium on Trichoptera. Ohio Biological Survey, Columbus, Ohio.

1997. Moulton, S.R., II, and K.W. Stewart. A new species and first record of the caddisfly genus Cnodocentron Schmid (Trichoptera: Xiphocentronidae) north of Mexico. Pages 343-347 in Proceedings of the VIII International Symposium on Trichoptera. Ohio Biological Survey, Columbus, Ohio.

1997. Stewart, K.W., and K.D. Alexander. Further considerations of mate searching behavior and communication in adult stoneflies (Plecoptera): First report of tremulation in Suwallia (Chloroperlidae). Pages 107-112 in P. Landolt and M. Sartori, editors, Ephemeroptera \& Plecoptera: Biology-Ecology-Systematics. Mauron \& Tinguley \& Lachat SA, Fribourg, Switzerland.

1997. Alexander, K.D., and K.W. Stewart. The importance of aedeagal characters in species delineation and revision of the stonefly tribe Suwalliini Surdick (Chloroperlidae). Pages 484-488 in P. Landolt and M. Sartori, editors, Ephemeroptera \& Plecoptera: Biology-Ecology-Systematics. Mauron \& Tinguley \& Lachat SA, Fribourg, Switzerland. 
1997. АввотT, J.C., And K.W. Stewart. Drumming of three Mesocapnia species (Capniidae) and Soliperla thyra (Peltoperlidae) from California, USA. Pages 88-92 in P. Landolt and M. Sartori, editors, Ephemoroptera \& Plecoptera: Biology-EcologySystematics. Mauron \& Tinguley \& Lachat SA, Fribourg, Switzerland.

1997. Stewart, K.W., AND W.E. Ricker. Stoneflies (Plecoptera) of the Yukon. Pages 202-222 in H.V. Danks and J.A. Downes, editors, Insects of the Yukon. Biological Survey of Canada (Terresrtial Arthropods), Ontario, Canada. Monograph Series 2.

1997. StewarT, K.W. Vibrational communication in insects; epitomy in the language of stoneflies. American Entomologist 43:81-91.

1997. Аввотt, J.C., K.W. Stewart, and S.R. Moulton II. Aquatic insects of the Big Thicket Region of East Texas. Texas Journal of Science (Supplement) 49: $35-50$.

1998. Houghton, D.C., And K.W. Stewart. Seasonal flight periodicities of six microcaddisflies (Trichoptera: Hydroptilidae, Glossossomatidae) in the Brazos River, Texas. Entomological News 109:103-109.

1998. Houghton, D.C., And K.W. Stewart. Life history and case building behavior of Culoptila cantha (Ross) (Trichoptera: Glossossomatidae) in the Brazos River, Texas. Annals of the Entomological Society of America 91:1-12.

1998. Houghton, D.C., AND K.W. Stewart. Immature life stage descriptions and distribution of Culoptila cantha (Ross) (Trichoptera: Glossossomatidae). Proceedings of the Entomological Society of Washington 100:511-520.

1998. Аввотt, J.C., And K.W. Stewart. Odonata of the south central Nearctic region, including northeastern Mexico. Entomological News 109:201-212.

1998. Stark, B.P., K.W. Stewart, S.W. SzczytKo, and R.W. Baumann. Common names of stoneflies (Plecoptera) from the United States and Canada. Ohio Biological Survey Notes 1:1-18.

1999. Alexander, K.D., and K.W. Stewart. Revision of the genus Suwallia Ricker (Plecoptera: Chloroperlidae). Transactions of the American Entomological Society 125:185-250.

2000. Gupta, T.S., AND K.W. Stewart. Life history and case building behavior of Molanna tryphena Betten (Trichoptera: Molannidae) in two East Texas springfed streams. Annals of the Entomological Society of America 93:65-74

2000. SteWart, K.W. Taeniopterygidae (the willowflies). Pages 55-89 in B.P. Stark and B.J. Armitage, editors, The stoneflies (Plecoptera) of eastern North America. Volume 1. Peltoperlidae, Pteronarcyidae, and Taeniopterygidae. Bulletin of the Ohio Biological Survey, New Series 14. Columbus, Ohio.

2001. STEWART, K.W. Vibrational communication (drumming) and mate-searching behavior of stoneflies (Plecoptera); Evolutionary considerations. Pages 217-226 in E. Dominguez, editor, Trends in Research in Ephemeroptera \& Plecoptera. Kluwer Academic/Plenum Publishers, New York, New York.

2001. Sandberg, J.B., and K.W. Stewart. Drumming behavior and life history notes of a high altitude population of the stonefly Isoperla petersoni Need- ham \& Christianson (Plecoptera: Perlodidae). Western North American Naturalist 61:445-451.

2002. Stewart, K.W., and B.P. Stark. Review and further description of eggs and females of the North American stonefly genus Setvena (Plecoptera: Perlodidae). Entomological News 113:87-93.

2002. Norwood, J.C., and K.W. Stewart. Life history and case building behaviors of Phylloicus ornatus (Banks) (Trichoptera: Calamoceratidae) in two springfed streams in the central Edwards Plateau bioregion of Texas. Annals of the Entomological Society of America 95:44-56.

2002. SzczYTKo, S.W., AND K.W. StEWART. New larval descriptions of 5 western Nearctic Isoperla: I. decolorata, I. denningi, I. rougensis, I. katmaiensis and I. baumanni and further descriptions of the male, female and ova of I. decolorata (Plecoptera: Isoperlinae). Transactions of the American Entomological Society 128:1-22.

2002. Stewart, K.W. Plecoptera (stoneflies). Pages 915919 in V.H. Resh and R. Carde, editors, Encyclopedia of insects. Academic Press, San Diego, California.

2002. Tierno de Figueroa, J.M., J.M. Luzon-Ortega, AND K.W. STEWART. The drumming of Isoperla pallida (Aubert) and Guadalgenus franzi (Aubert) (Plecoptera: Perlodidae), and review and evolutionary considerations of southern Iberian Peninsula Perlodidae. Zoological Science (Japan) 19:871-875.

2002. Stewart, K.W., and B.P. Stark. Nymphs of North American stonefly genera (Plecoptera). 2nd edition. Caddis Press, Columbus, Ohio. 510 pp.

2003. Stewart, K.W., and J.B. Sandberg. The life history of a Colorado population of Kogotus modestus (Plecoptera: Perlodidae). Pages 195-200 in E. Gaino, editor, Research update on Ephemeroptera \& Plecoptera. Università di Perugia, Perugia, Italy.

2003. Sandberg, J.B., and K.W. Stewart. Continued studies of drumming in North American Plecoptera; evolutionary implications. Pages 73-81 in E. Gaino, editor, Research update on Ephemeroptera \& Plecoptera. Università di Perugia, Perugia, Italy.

2004. SteWART, K.W. Vibrational communication in insects. Pages 2462-2464 in J.L. Capenira, editor, Encyclopedia of entomology. Volume 3. Kluwer Academic Publishers.

2004. Stewart, K.W. Drumming communication and intersexual searching behavior of stoneflies (Plecoptera). Pages 724-726 in J.L. Capenira, editor, Encyclopedia of entomology. Volume 1. Kluwer Academic Publishers.

2004. Stewart, K.W. Plecoptera (stoneflies). Pages 141146 in M. Hutchins, A.V. Evans, R.W. Garrison, and N. Schlager, editors, Grzimek's animal life encyclopedia. 2nd edition, Volume 3. Farmington Hills, Michigan.

2004. SzcZYTKO, S.W., AND K.W. STEWART. Isoperla muir a new species of western Nearctic Isoperla and a new larval description of Isoperla tilasqua Szczytko and Stewart (Plecoptera: Isoperlinae). Transactions of the American Entomological Society 130:233-243.

2004. Petr, D., and K.W. Stewart. Comparative morphology of sensilla styloconica on the proboscis of North American Nymphalidae and other selected taxa (Lepidopera): Systematic and ecological 
considerations. Transactions of the American Entomological Society 130:293-409.

2004. Stewart, K.W., and J.B. Sandberg. Description of the nymph and drumming calls of Megaleuctra complicata Claassen (Plecoptera: Leuctridae); Evolution of drumming in Leuctridae. Aquatic Insects 26:123-129.

2004. SandberG, J.B., AND K.W. Stewart. Capacity for extended egg diapause in six Isogenoides Klapálek species (Plecoptera: Perlodidae). Transactions of the American Entomological Society 130:411-423.

2005. SandberG, J.B., AND K.W. Stewart. Life history of the stonefly Isogenoides zionensis (Plecoptera: Perlodidae) from the San Miguel River, Colorado. Illesia 1(4):1-12.

2005. SAndBerg, J.B., AND K.W. SteWART. Vibrational communication (drumming) of the Nearctic stonefly genus Isogenoides (Plecoptera: Perlodidae). Transactions of the American Entomological Society 131:111-130.

2005. Stark, B.P., and K.W. Stewart. Nymphs of four western Nearctic Sweltsa species (Plecoptera: Chloroperlidae). Transactions of the American Entomological Society 131:189-200.

2005. SandberG, J.B., AND K.W. SteWART. Holomorphology and systematics of the stonefly genus Isogenoides (Plecoptera: Perlodidae). Transactions of the American Entomological Society 131:269-348.

2005. Stewart, K.W., and J.B. Sandberg. Vibrational communication and mate searching behavior in stoneflies (Plecoptera). Pages 193-200 in S. Drosopoulos and M. Claridge, editors, Insect sounds and communication. CRC Press.

2006. SAndberG, J.B., AND K.W. SteWART. 2006. Continued studies of vibrational communication (drumming) of North American Plecoptera. Illiesia 2:1-14.

2006. Stewart, K.W., AND M.W. Oswood. The stoneflies (Plecoptera) of Alaska and western Canada. Caddis Press, Columbus, Ohio. 325 pp.

2007. Stewart, K.W., and E.F. Drake. The nymphs of two rare western stonefly (Plecoptera) species, representing little-known genera. Transactions of the American Entomological Society 133:115-122.

2008. Stewart, K.W., and B.P. Stark. Plecoptera. Pages 311-384 in R.W. Merritt, K.W. Cummins, and M.B. Berg, editors, An introduction to the aquatic insects of North America. 4th edition. Kendall/Hunt Publishing Company, Dubuque, Iowa.

2008. Stewart, K.W., And N.H. Anderson. The nymphs of three Nemouridae species (Plecoptera) from Oregon temporary headwater streams. Transactions of the American Entomological Society 134:173-183.

2008. Earle, J.I., AND K.W. SteWart. Description of the nymph of Strophopteryx appalachia Ross \& Ricker (Plecoptera: Taeniopterygidae), and key to Strophopteryx nymphs. Proceedings of the Entomological Society of Washington 110:551-555.
2009. Stewart, K.W. Plecoptera (stoneflies). Pages 810 813 in V.H. Resh and R.T. Carde, editors, Encyclopedia of insects. 2nd edition. Elsevier.

2009. Stewart, K.W., And N.H. Anderson. The life history and nymphal generic character development of Sweltsa adamantea Surdick (Plecoptera: Chloroperlidae) in an Oregon summer-dry, headwater stream. Transactions of the American Entomological Society 135:161-173.

2009. Stewart, K.W., and N.H. Anderson. The life history and nymphal generic character development of Malenka bifurcata (Claassen) (Plecoptera: Nemouridae) in an Oregon summer-dry stream. Aquatic Insects (Supplement 1) 31:391-399.

2009. Baumann, R.W., and K.W. Stewart. What is Capnia umpqua Frison? (Plecoptera: Capniidae), distribution and variation of terminalia. Illiesia 5:34-39.

2009. Stewart, K.W. New descriptions of North American Taenionema larvae (Plecoptera: Taeniopterygidae). Illiesia 5:128-145.

2010. Stewart, K.W. The larva of Paracapnia disala (Jewett) (Plecoptera: Capniidae). Illiesia 6:11-15.

2010. Stewart, K.W., and N.H. Anderson. The life history of Ostrocerca dimicki (Plecoptera: Nemouridae) in a short-flow Oregon temporary stream. Illiesia 6:52-57.

2010. Stewart, K.W., and N.H. Anderson. The life history of Soyedina producta (Claassen) (Plecoptera: Nemouridae) in an Oregon summer-dry stream, with notes on its larval generic character development. Illiesia 6:227-233.

2011. Stark, B.P., B.C. KondratiefF, R.F. Kirchner, AND K.W. STEWART. Larvae of eight eastern North American Sweltsa (Plecoptera: Chloroperlidae). Illiesia 7:104-117.

2011. SteWart, K.W., AND B.P. Stakk. Further descriptions of western North American Podmosta larvae and their separation from Ostrocerca larvae (Plecoptera: Nemouridae). Illiesia 7:104-117.

2011. Stewart, K.W., E.F. Drake, and B.P. Stark. Larvae of five species of the winter stonefly genus Capnia (Plecoptera: Capniidae) from California, U.S.A. Illiesia 7:167-181.

2012. Stewart, K.W., And B.C. KondratiefF. Larvae of the Nearctic species of the stonefly genus Megarcys Klapálek (Plecoptera: Perlodidae). Illiesia 8:16-36.

2012. Stark, B.P., K.W. SteWart, S.W. SzczytKo, R.W. Baumann, and B.C. Kondratieff. Scientific and common names of Nearctic stoneflies (Plecoptera), with corrections and additions to the list. Caddis Press, Miscellaneous Contributions 1:1-20.

2013. Stewart, K.W., B.P. Stark, And L.E. Serpa. Larvae of the two North American species of Calileuctra (Plecoptera: Leuctridae). Illiesia 9:1-13. 